\title{
Path analysis and canonical variables of intervarietal maize hybrids
}

\section{Mauricio Horbach Barbosa', Ivan Ricardo Carvalho ${ }^{1}$, Vinícius Jardel Szareski ${ }^{1}$, Giordano Gelain Conte ${ }^{1}$, Alan Junior de Pelegrin ${ }^{1}$, Mauricio Ferrari ${ }^{1}$, Tiago Corazza da Rosa ${ }^{1}$, Ritieli Baptista Mambrin ${ }^{2}$, Maicon Nardino ${ }^{1}$, Antonio Costa de Oliveira ${ }^{1}$, Luciano Carlos da Maia ${ }^{1}$, Velci Queiróz de Souza ${ }^{3}$}

\author{
${ }^{1}$ Universidade Federal de Pelotas, CEP 96010-610, Capão do Leão, RS, Brazil \\ ${ }^{2}$ Universidade Federal de Santa Maria, Santa Maria, RS, Brazil \\ ${ }^{3}$ Universidade Federal do Pampa, São Gabriel, RS, Brazil
}

\section{*Corresponding authors:hbmauricio@yahoo.com.br}

\begin{abstract}
Maize (Zea mays L.) is the cereal most produced in the world, due to its wide scope and utilization in human and animal diet. This study aims to evaluate the agronomic performance of intervarietal maize hybrids, as well as the linear associations, interrelations of cause and effect, and the genotypes dispersion through canonical variates. The experiment was conducted in the agricultural year of 2014/2015. The crosses that originated the hybrids were carried out on the growing season of 2013/2014 and hybrids evaluated on 2014/2015. The hybrids were arranged in randomized blocks, being 13 treatments with five repetitions. The measured characters were: plant height, spike insertion height, stem diameter, spike diameter, spike length, spike mass, number of rows of grains per spike, number of grains per row, cob diameter, cob mass, spike grains mass, mass of a thousand grains, gra in length and grain yield. The data were submitted to analysis of variance and mean values compared by the Tukey test at $5 \%$ of probability. The Pearson's linear correlation analysis and path analysis were performed using grain yield as a dependent character. Furthermore, the analysis of canonical variables was carried out. The hybrid $H_{5}: G 3 X G 4$ revealed higher grain yield, spike grains mass, number of grains per row and spike diameter. Grain yield of intervarietal hybrids presented positive correlations with the traits such as stem diameter, spike diameter, spike length, number of grains per row, mass of a thousand grains, grain length and spike grains mass. Spike diameter and spike length presented higher direct effects on grain yield of intervarietal hybrids. The canonical variates revealed the formation of five phenotypically distinct groups of intervarietal hybrids.
\end{abstract}

Keywords: Zea mays L., biometric models, interrelationships, analysis multivariate.

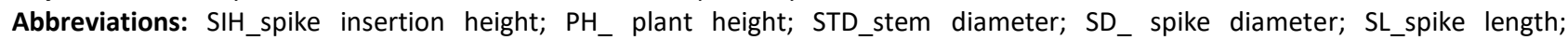
NRG_number of rows of grains; NGR_number of grains per row; MTG_mass of a thousand grains; GL_grains length; SGM_spike grains mass; GY_grain yield.

\section{Introduction}

Maize (Zea mays) is the most produced cereal in the world due to its wide scope and utilization in human and animal diet. In Brazil, maize is the most produced cereal which corresponds to more than one third of the national grain production, and the production in the agricultural year 2015/2016 may surpass 83 million tons. The Brazilian average grain yield is close to $5,432 \mathrm{~kg} \mathrm{ha}^{-1}$, which is more than the Rio Grande do Sul state average of $3,627 \mathrm{~kg} \mathrm{ha}^{-1}$ (Conab, 2016).

The productive performance of maize hybrids is closely related to biotic and abiotic effects, as well as the intrinsic features of each genotype (Troyjack et al., 2018). The selection of the hybrid that better adapts to environmental conditions, and cultural traits becomes fundamental, as it presents great influence in the final yield (Cruz and Carneiro, 2003; Pelegrin et al., 2017; Szareski et al., 2018; Nardino et al., 2018). According to Miranda Filho et al. (1987), hybrids may be classified as single-cross, modified single cross, triple-cross, modified triple cross, double-cross, top cross and intervarietal.

In the actual agricultural scenario, the utilization of singlecross hybrids is usually emphasized due to their higher yield potential. However, single cross hybrid seeds have elevated costs, hindering the access of farmers with lower technological level (Doná et al., 2011; Nardino et al., 2016; Demari et al., 2018). Thus, triple, double, and intervarietal hybrids are important alternatives to farmers, once they may present higher phenotypic stability in unfavorable scenarios (Da Rosa et al., 2018).

Understanding of agronomic behavior and associations among traits are crucial to maize breeding, evidencing which genotypes and traits are determinant for the grain yield. On this context, the Pearson's linear correlation coefficient allows to achieve the linear association tendency between two traits, allowing the breeders to guide the selection for determined characteristic (Moore, 2007; Szareski et al., 2018). Therefore, it is necessary to have knowledge about 
morphologic traits association and maize grain yield. It has been reported that close relation imposed by linear correlation results in unreliable estimates (Cruz et al., 2004; Carvalho et al., 2018). On this way, it is necessary to analyze the interrelations, detailing the determining effects to the main trait. Therefore, path analysis promotes the correlation coefficient deployment in a cause and effect relation between traits (Cruz and Carneiro, 2003).

Aiming to comprehend the genetic variation between intervarietal hybrids, multivariate and canonical variate analyses may be used. It allows interpreting the measured traits in a simple and joint way, being represented by a bi or tridimensional graphic dispersion of the scores (Cruz et al., 2012). Its results allow the grouping of similar genotypes (Cruz et al., 2012). Therefore, this study aims to evaluate the agronomic performance of intervarietal maize hybrids, as well as the linear associations, interrelations of cause and effect, and the genotypes dispersion through canonical variates.

\section{Results and discussion}

The variance analysis revealed significance for the traits spike insertion height (SIH), stem diameter (STD), spike diameter (SD), spike length (SL), number of grains per row (NGR), mass of a thousand grains (MTG), spike grains mass (SGM), and grain yield (GY). Plant height (PH) cob diameter $(C D)$, grain length $(\mathrm{GL})$ and cob mass $(\mathrm{CM})$ presented no significant differences among genotypes.

The coefficient of variation is a measure of relative precision originated from standard deviation and arithmetic mean, which depends to the nature of the trait (Silva, 2003). The traits plant height (PH), stem diameter (STD), spike diameter $(\mathrm{SD})$, spike length (SL), and grain length (GL) presented coefficient of variation (CV) less than $10 \%$, by which high experimental precision is attributed to these traits. The traits spike insertion height $(\mathrm{SIH})$, and number of grains per row (NGR) evidenced mean experimental precision, with coefficients of variation ranging from 10 to $20 \%$ (Pimentel Gomes, 2009).

The traits spike grains mass (SGM) and grain yield (GY) presented higher coefficient of variation, more than $20 \%$, being considered of low experimental precision according to the classification of Pimentel Gomes (2009). However, Silva (2003) affirmed that interpretation of coefficient of variation must be carried out based on the scale of reference with coefficients of variation correspondent to the same trait measured in similar experiments, conducted with the same species and environmental conditions, where the levels of precision are known. Scapim et al. (1995), proposed a method for classification of coefficient of variation of maize, in which the spike grains mass and grain yield showed mean experimental precision, evolving the particularities of the crop.

For the trait spike insertion height $(\mathrm{SIH})$, the cross $\left(\mathrm{H}_{6}\right): P_{5} X$ $P_{4}$ evidenced the highest magnitude, differing from hybrids $\mathrm{H}_{1}$ and $\mathrm{H}_{4}$ (Table 2). Possamai et al. (2001), reported that plants with higher spike insertion height have advantages for harvesting, elevating the efficiency of this operation at field. According to Silva et al. (2005), the differences observed for spike insertion height are due to genetic divergences between genetic background of hybrids. However, this trait is greatly influenced by environment conditions and cultural traits. Thus, alterations may occur when the hybrids are cultivated in other environments.

Stem diameter in plant structure supports inflorescence and leaves. Besides, it serves as storage of assimilates that will be used in reproductive period by plants, on grains formation (Fancelli and Dourado Neto, 2000). The hybrids $\mathrm{H}_{9}: P_{4} X P_{1}$ and $\mathrm{H}_{11}: P_{3} X P_{1}$ evidenced the highest magnitudes for this trait (Table 2). It reveals that the utilization of the hybrid G1 as male genitor on crosses with the varieties G4 and $\mathrm{G} 3$ resulted on the increment of this trait. Thus, crossing a narrow genetic base hybrid with an open pollination variety tends to increment stem diameter.

The performance of the hybrids for the traits spike grains mass (SGM) and grain yield were similar, where the hybrid $\mathrm{H}_{5}: P_{3} X P_{4}$ was superior to $\mathrm{H}_{12}: P_{4} X P_{2}$ and $\mathrm{H}_{13}: P_{1} X P_{5}$. Thus, the crossing between two open pollination varieties (G3 $\mathrm{X}$ G4) resulted in a higher increment on grain yield presenting the greatest allelic complementarity, also associated with dominancy deviations (Miranda Filho, 1987). Besides, the maternal effect was indirectly observed on the hybrids $\mathrm{H}_{1}$ and $\mathrm{H}_{12}$, where the cross $\mathrm{H}_{1}: G 2 \times G 4$ produced $1,304 \mathrm{~kg} \mathrm{ha}^{-1}$ more than the hybrid $\mathrm{H}_{12}: G 4 X G 2$. The maternal effects are either associated with nuclear genes originated on the nucleus of the female genitor, and genes located on the chloroplasts and mitochondria (Ramalho et al., 2012).

For the trait number of grains per row (NGR), the hybrid $\mathrm{H}_{5}$ was superior to the hybrids $\mathrm{H}_{4}, \mathrm{H}_{12}$ and $\mathrm{H}_{13}$ and for the other hybrids, no significant differences were observed. Study conducted by Vilela et al. (2012), also observed significant differences among hybrids for this trait, linking this effect to the intrinsic genetic constitution of the hybrid. The number of grains per row is defined before flowering, around stage V17. However, climatic conditions and nutritional levels are fundamental to formation and filling of grains (Magalhães; Durães, 2006).

For the trait spike diameter (SD), we evidenced that hybrids originated from the crosses between open pollinated variety G3 and the genitor G1 and G4 resulted a better increment, once the hybrids $\mathrm{H}_{3}$ and $\mathrm{H}_{5}$ presented the highest magnitudes and differ of the hybrid $\mathrm{H}_{13}$. The utilization of the genitor G3 for the formation of intervarietal hybrids must be prioritized when the goal is to achieve spikes of greater diameter. Studies conducted by Hallauer et al. (2010), revealed that the heritability on the narrow sense for this trait ranges from 0.30 to 0.50 , being classified as a trait of moderated heritability.

For the trait spike length (SL), we observed that the hybrid $\mathrm{H}_{11}$ differed from hybrid $\mathrm{H}_{4}$; however, the other hybrids evidenced no significant differences. Thus, a lower variation is observed among the hybrids evaluated for this trait. These results are similar to those found by Gilo et al. (2011), who affirm that most of the studied hybrids statistically equalize among themselves for the trait spike length. On the other hand, study conducted by Fernandes et al. (2010) reported that spike length reveals high heritability, being little influenced by the environment.

The Pearson's linear correlation for the eleven morphologic traits and grain yield, revealed 55 linear associations, being 27 significant by the test $t$ ( $p<0.05$ of probability) (Table 3 ). The trait spike insertion height $(\mathrm{SIH})$ revealed intermediate and positive correlation with plant height $(r=0.36)$ and spike diameter $(r=0.31)$. The correlation with the same magnitude 
Table 1. Genotypes used as parent of the crosses on the 2013/2014 growing season.

\begin{tabular}{ll}
\hline Genotypes & Genetic base \\
\hline G1 & Single cross hybrid \\
G2 & Double cross hybrid \\
G3 & Open Pollination Variety \\
G4 & Open Pollination Variety \\
G5 & Open Pollination Variety \\
\hline
\end{tabular}

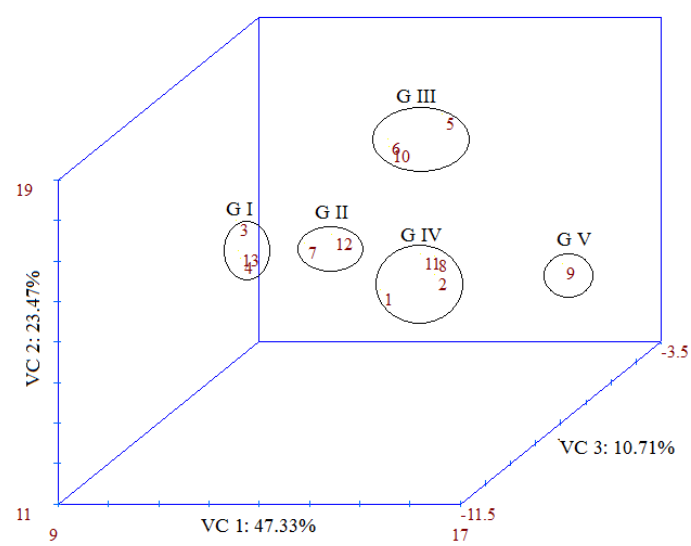

Fig 1. Dispersion of thirteen intervarietal maize hybrids considering the first three canonical variates. Dispersion achieved through the measurement of eleven traits.

Table 2. Comparison of means for the traits spike insertion height (SIH), stem diameter (STD), spike length (SL), number of grain s per row (NGR), spike diameter (SD), spike grains mass (SGM), and grain yield (GY) among genotypes.

\begin{tabular}{|c|c|c|c|c|c|c|c|}
\hline Crosses/Genotypes & STD $(\mathrm{cm})$ & STD $(\mathrm{mm})$ & $\mathrm{SD}(\mathrm{mm})$ & $\mathrm{SL}(\mathrm{cm})$ & NGR (uni) & SGM (g) & $\mathrm{GY}\left(\mathrm{kg} \mathrm{ha}^{-1}\right)$ \\
\hline $\mathrm{G} 2 \times \mathrm{G} 4\left(\mathrm{H}_{1}\right)$ & 106. $d$ & $20.5 c d e$ & $42.384 \mathrm{ab}$ & 14.40ab & $32.60 \mathrm{ab}$ & $109.84 a b$ & $8787 a b$ \\
\hline $\mathrm{G} 1 \times \mathrm{G} 2\left(\mathrm{H}_{2}\right)$ & $130 \mathrm{abcd}$ & $23.944 \mathrm{bc}$ & $41.902 \mathrm{ab}$ & $15.30 \mathrm{ab}$ & $34.00 \mathrm{ab}$ & $103.79 a b$ & $8303 a b$ \\
\hline $\mathrm{G} 1 \times \mathrm{G} 3\left(\mathrm{H}_{3}\right)$ & $136 \mathrm{abcd}$ & 16.228 ef & $45.622 \mathrm{a}$ & $16.50 \mathrm{ab}$ & $31.40 \mathrm{ab}$ & $130.46 a b$ & $10436 a b$ \\
\hline $\mathrm{G} 5 \times \mathrm{G} 2\left(\mathrm{H}_{4}\right)$ & $122 \mathrm{~cd}$ & $15.924 \mathrm{f}$ & $41.834 \mathrm{ab}$ & $14.10 \mathrm{~b}$ & $29.20 \mathrm{~b}$ & $103.98 a b$ & $8319 a b$ \\
\hline $\mathrm{G} 3 \times \mathrm{G} 4\left(\mathrm{H}_{5}\right)$ & $156 a b$ & $22.498 \mathrm{bcd}$ & $47.038 \mathrm{a}$ & $17.00 \mathrm{ab}$ & $40.00 \mathrm{a}$ & $158.01 \mathrm{a}$ & $12641 \mathrm{a}$ \\
\hline G5 X G4 $\left(\mathrm{H}_{6}\right)$ & 159 a & 20.770 bcde & $43.872 a b$ & $15.00 \mathrm{ab}$ & $34.60 \mathrm{ab}$ & $122.63 \mathrm{ab}$ & $9811 a b$ \\
\hline $\mathrm{G} 2 \times \mathrm{G} 1\left(\mathrm{H}_{7}\right)$ & $128 \mathrm{abcd}$ & 19.094 def & $43.776 \mathrm{ab}$ & $15.80 \mathrm{ab}$ & $33.40 \mathrm{ab}$ & $110.38 \mathrm{ab}$ & $8830 \mathrm{ab}$ \\
\hline $\mathrm{G} 5 \times \mathrm{G} 1\left(\mathrm{H}_{8}\right)$ & $126 \mathrm{cbd}$ & $23.280 \mathrm{bcd}$ & $42.372 \mathrm{ab}$ & $16.00 \mathrm{ab}$ & $36.40 \mathrm{ab}$ & $120.75 a b$ & $9660 a b$ \\
\hline $\mathrm{G} 4 \times \mathrm{G} 1\left(\mathrm{H}_{9}\right)$ & $130 \mathrm{abcd}$ & $28.720 \mathrm{a}$ & $42.698 a b$ & $15.50 \mathrm{ab}$ & $34.40 \mathrm{ab}$ & $122.28 \mathrm{ab}$ & $9783 a b$ \\
\hline G4 X G5 $\left(\mathrm{H}_{10}\right)$ & $153 a b c$ & 20.484 cdef & $44.708 a b$ & $14.70 \mathrm{ab}$ & $30.60 \mathrm{~b}$ & $123.74 a b$ & $9899 a b$ \\
\hline $\mathrm{G} 3 \times \mathrm{G} 1\left(\mathrm{H}_{11}\right)$ & $136 \mathrm{abcd}$ & $25.206 a b$ & $41.874 \mathrm{ab}$ & $17.30 \mathrm{a}$ & $31.80 \mathrm{ab}$ & $128.38 \mathrm{ab}$ & $10271 a b$ \\
\hline $\mathrm{G} 4 \times \mathrm{G} 2\left(\mathrm{H}_{12}\right)$ & $133.4 \mathrm{abcd}$ & $18.826 \mathrm{def}$ & $42.348 a b$ & $14.50 \mathrm{ab}$ & $29.80 \mathrm{~b}$ & $93.53 \mathrm{~b}$ & $7483 \mathrm{~b}$ \\
\hline $\mathrm{G} 1 \times \mathrm{G} 5\left(\mathrm{H}_{13}\right)$ & $136 \mathrm{abcd}$ & $16.440 \mathrm{ef}$ & $39.240 \mathrm{~b}$ & $15.20 \mathrm{ab}$ & $30.20 \mathrm{~b}$ & $88.37 \mathrm{~b}$ & $7070 \mathrm{~b}$ \\
\hline CV (\%) & 10.84 & 9.93 & 6.55 & 9.01 & 12.3 & 22.00 & 22.00 \\
\hline
\end{tabular}

${ }^{*}$ Means followed by the same uncapitalized letter on the column did not statistically differ by the Tukey test with $5 \%$ of probability.

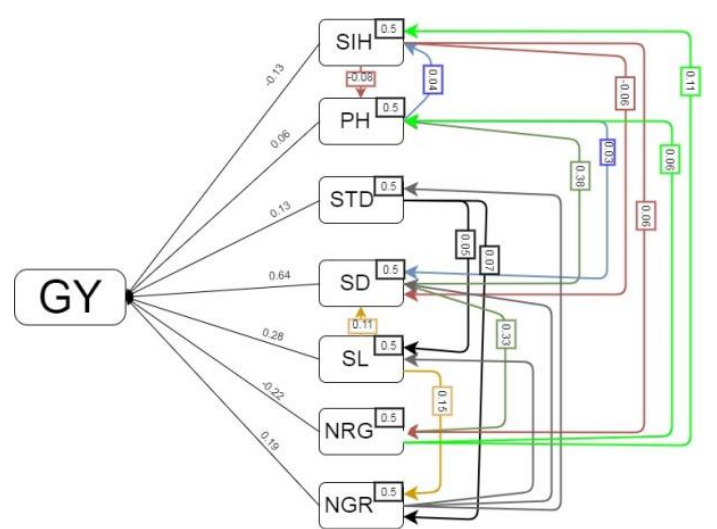

Fig 2. Path analysis diagram of direct and indirect effects for spike insertion height (SIH), plant height (PH), stem diameter (STD), spike diameter (SD), spike length (SL), number of rows of grains (NRG), number of grains per row (NGR), confronted with the dependent trait grain yield (GY), measured in intervarietal maize hybrids. 
Table 3. Pearson's linear correlation for spike insertion height (SIH), plant height (PH), stem diameter (STD), spike diameter (SD), spike length (SL), number of rows of grains (NRG), number of grains per row (NGR), mass of a thousand grains (MTG), grains le ngth $(\mathrm{GL})$, spike grains mass (SGM) and grain yield (GY), measured in maize intervarietal hybrids.

\begin{tabular}{|c|c|c|c|c|c|c|c|c|c|c|c|}
\hline & $\mathrm{SIH}$ & $\mathrm{PH}$ & STD & SD & $\mathrm{SL}$ & NRG & NGR & MTG & $\mathrm{GL}$ & SGM & $\mathrm{GY}$ \\
\hline SIH & - & $0.36^{*}$ & -0.01 & $0.31 *$ & 0.063 & -0.07 & 0.11 & 0.23 & 0.23 & 0.21 & 0.21 \\
\hline $\mathrm{PH}$ & & - & -0.01 & $0.32 *$ & -0.10 & 0.024 & -0.11 & 0.15 & 0.17 & 0.14 & 0.14 \\
\hline STD & & & - & 0.022 & $0.31 *$ & -0.02 & $0.38 *$ & 0.19 & 0.14 & $0.27^{*}$ & $0.27^{*}$ \\
\hline SD & & & & - & 0.24 & $0.39 *$ & $0.30 *$ & $0.47^{*}$ & $0.58^{*}$ & $0.71 *$ & $0.71^{*}$ \\
\hline SL & & & & & - & -0.05 & $0.56^{*}$ & 0.33 & $0.17^{*}$ & $0.60 *$ & $0.60^{*}$ \\
\hline NRG & & & & & & - & 0.04 & $-0.34 *$ & -0.05 & 0.08 & 0.08 \\
\hline NGR & & & & & & & - & 0.19 & $0.34^{*}$ & $0.57^{*}$ & $0.57^{*}$ \\
\hline MTG & & & & & & & & - & $0.75^{*}$ & $0.75^{*}$ & $0.75^{*}$ \\
\hline $\mathrm{GL}$ & & & & & & & & & - & $0.74 *$ & $0.74 *$ \\
\hline SGM & & & & & & & & & & - & $0.99 *$ \\
\hline GY & & & & & & & & & & & - \\
\hline
\end{tabular}

Table 4. Estimates of direct and indirect effects for spike insertion height (SIH), plant height (PH), stem diameter (STD), spike diameter (SD), spike length (SL), number of rows of grains (NRG), number of grains per row (NGR), confronted with the dependent trait grain yield (GY), measured in intervarietal maize hybrids.

\begin{tabular}{|c|c|c|c|c|c|c|c|}
\hline \multirow{2}{*}{ Effects } & \multicolumn{7}{|c|}{ Independent traits } \\
\hline & $\mathrm{SIH}$ & $\mathrm{PH}$ & STD & SD & $\mathrm{SL}$ & NRG & NGR \\
\hline Direct & -0.13 & 0.06 & 0.13 & 0.64 & 0.28 & -0.22 & 0.19 \\
\hline Ind. through SIH & - & -0.08 & -0.00 & -0.06 & -0.04 & 0.06 & -0.03 \\
\hline Ind through $\mathrm{PH}$ & 0.04 & - & 0.00 & 0.03 & 0.00 & -0.01 & 0.00 \\
\hline Ind. through STD & 0.00 & 0.00 & - & 0.00 & 0.05 & -0.00 & 0.07 \\
\hline Ind. through SD & 0.32 & 0.38 & 0.02 & - & 0.246 & 0.07 & 0.33 \\
\hline Ind. through SL & 0.08 & 0.03 & 0.10 & 0.11 & - & -0.02 & 0.15 \\
\hline Ind. through NRG & 0.11 & 0.06 & 0.00 & -0.02 & 0.01 & - & -0.02 \\
\hline Ind. through NGR & 0.05 & 0.00 & 0.10 & 0.10 & 0.10 & 0.01 & - \\
\hline Total & 0.50 & 0.45 & 0.38 & 0.82 & 0.68 & -0.11 & 0.70 \\
\hline \multicolumn{3}{|c|}{ Coefficient of determination } & 0.90 & & & & \\
\hline \multicolumn{3}{|c|}{$\mathrm{K}$ value used in the analysis } & 4.11 & & & & \\
\hline \multicolumn{3}{|c|}{ Effect of the residual variable } & 0.31 & & & & \\
\hline \multicolumn{3}{|c|}{ Determinant of the matrix } & 6.57 & & & & \\
\hline
\end{tabular}

and sense was evidenced between the plant height and stem diameter $(r=0.32)$. These associations revealed tendency of plant height increment jointly to the increment of spike insertion height and stem diameter. These results corroborate with Kleinpaul et al. (2014), which reveals positive associations between plant height and spike insertion height.

The correlation allows comprehending the occurrence of associations between traits (Churata and Ayala-Osuna, 1996; Carvalho et al., 2017). On this way, the trait stem diameter revealed coefficient of correlation intermediate and positive with SL $(r=0.30)$ and NGR $(r=0.37)$ and weak and positive with SGM ( $r=0.27)$ and GY $(r=0.27)$. The stem diameter is an important morphologic trait associated with grain yield, as it acts as sustentation and structure of energetic storage. Therefore, plants with larger stem diameter tend to present bigger energetic reserves, which are accumulated during the vegetative period and translocated to the spike during grains formation and filling (Fancelli and Dourado Neto, 2000; Baretta et al., 2017). Studies of Cruz et al. (2008), also revealed strong and positive associations between stem diameter and grain yield.

Spike diameter (SD) presented strong and positive correlation with SGM ( $r=0.71)$ and GY (0.71), intermediate and positive with MTG $(r=0.46)$ and $G L(r=0.59)$, weak and positive with NGR ( $r=0.29)$. Due to the increment of grain length, we evidenced a tendency of increment of spike diameter, increment of grains mass and mass of a thousand grains, as well as grain yield. These results corroborate with Entringer et al. (2014), which observed positive correlations between spike diameter and grain length, volume of grains and spike mass. Spike length (SL) presented strong and positive correlations with number of grains per row $(r=0.56)$, spike grains mass $(r=0.60)$ and grain yield $(r=0.60)$, weak and positive with grain length $(r=0.17)$. Therefore, as higher the spike length is, there is an increment on number of grains to be formed in the rows of the spike (Goes et al., 2012; Nardino et al., 2017).

The mass of a thousand grains (MTG) revealed strong and positive correlation coefficient with the traits $G L(r=0.75)$, 
SGM ( $r=0.75)$ and GY $(r=0.75)$, intermediate and negative with NRG ( $r=-0.34)$. Therefore, the increment on grain length relates with the increment of mass of a thousand grains, as larger grains elevate the volume of grains, due to the increment of reserve substances and formation of grains with bigger mass. The bigger mass of a thousand grains is associated with the smaller number of rows of grains. These results corroborate with Entringer et al. (2014), where the increment of grain length is directly proportional to the increment of grain volume and spike mass. However, there is a reduction in the number of rows of grains per spike.

The spike grains mass (SGM) revealed strong and positive correlation with grain yield $(r=0.99)$. The high correlation between these traits is expected because they are closely related. According to Lopes et al. (2007), grain mass is directly related with mass of grains per spike, and determining to grain yield. Besides, these traits are influenced by several components, among them, spike grains mass, number of grains per row, spike length and diameter (Lima et al., 2006).

The Pearson's correlation is a mean of associations between two traits, emphasizing that correlation between traits does not allow inferring on cause and effect relation (Vencovsky and Barriga, 1992; Churata and Ayala-Osuna, 1996). Thereby, for determining the direct and indirect influence of a trait to another and associations of cause and effect, the path analysis is applied, showing deployment in direct and indirect effects of independent traits on the dependent (Wright, 1921). Aiming to reduce the collinearity of the phenotypic correlation matrix, the traits spike grains mass (SGM) was removed from the phenotypic matrix. Then, a weak collinearity was achieved, considering grain yield as the main trait (Table 4).

Spike diameter and spike length present direct effect for increasing grain yield. Besides, this trait showed indirect and positive effects on the number of grains per row. This result corroborates with Fancelli and Dourado Neto (1999), which evidenced that spike diameter and length directly increase grain yield. According to Lopes et al. (2007), the best strategy is the simultaneous selection of traits, giving preference to traits with higher indirect effects. Besides, the heritability in the narrow sense must be considered to proceed future selections (Cruz et al., 2004).

The trait number of rows of grains revealed negative direct effect $(-0.22)$ on grain yield, and indirect effects did not contribute to the dependent trait. Thus, the reduction of number of rows of grains per spike results in the increase of grain yield, because, both direct effect and linear correlation presented similar sense and magnitude. Contradictory results were obtained by Balbinot Junior et al. (2005), where the trait number of rows per spike presented the highest direct effect on grain yield of open pollination varieties.

The trait spike insertion height presented total positive effect on grain yield; however, the direct effect of this trait on grain yield was negative $(-0.130)$. These results are spurious due the final response being influenced mainly by spike diameter and number of rows of grains. Study conducted by Barbosa et al. (2016) evidenced no direct effect of spike insertion height on grain yield of triple cross hybrids.

The direct effect of stem diameter on grain yield was low and positive $(0,139)$, and the indirect effects of spike length and number of grains per row contributed to increase the total linear associations. According to Jasdanwazla and Khan (1988), the open pollination varieties and hybrids presented physiological alterations regarding photoassimilates translocation, and their fraction on the traits related to the spike.

Canonical variates are linear combinations of original traits that aim to simplify the structure of the data (Cruz and Regazzi, 1997). Three canonical variates were necessary to represent $81.51 \%$ of the total variation of the hybrids, where the first canonical variate represented $47.33 \%$, the second $23.47 \%$, and the third $10.71 \%$ of the total genetic variation (Figure 1). According to Cruz et al. (2012), only when the first three canonical variates explain more than $80 \%$ of the total variation, its utilization is satisfactory to distinguish genotypes through the tridimensional graphic dispersion.

The graphic dispersion for the 13 intervarietal hybrids reveals the formation of five groups, being the group I formed by the hybrids $\mathrm{H}_{3}$ : $G 1 \times G 3, \mathrm{H}_{4}: G 5 \times G 2, \mathrm{H}_{13}: G 1 \times$ G5. The group II was formed by the hybrids $\mathrm{H}_{7}: G 2 X G 1$ and $\mathrm{H}_{12}$ : G4 X G2. The hybrids that constitute the arbitrary groups present higher similarity than the highlighted hybrids (Miranda et al., 2003). The group III was formed by the hybrids $\mathrm{H}_{5}$ : $G 3 \times G 4, \mathrm{H}_{6}$ : $G 5 \times G 4$ and $\mathrm{H}_{10}$ : $G 4 X G 5$. Thus, only on the group III, the reciprocal crosses $\mathrm{H}_{6}$ : $G 5 X G 4$ and $\mathrm{H}_{10}$ : G4 $X$ G5 remained phenotypically close, jointly with the crossing of two open pollination varieties, which have broad genetic base.

The group IV was formed by the hybrids $\mathrm{H}_{1}$ : $G 2 \times G 4, \mathrm{H}_{2}$ : $G 1$ $X G 2, \mathrm{H}_{8}$ : G5 $X G 1$ and $\mathrm{H}_{11}$ : $G 3 X G 1$ and the group $\mathrm{V}$ was formed by the hybrid $\mathrm{H}_{9}$ : G4 $X$ G1. The utilization of genitors/parents with narrow genetic base (G2 and G1) results in greater phenotypic variation for the hybrids originated from these crosses, once the allelic complementarity between genitors assumes aleatory patterns, resulting in distinct intervarietal hybrids.

\section{Materials and methods}

\section{Experimental Conditions}

The experiment was conducted in the agricultural year of $2014 / 2015$, at the experimental area of the Center of Genomics and plant breeding of the Federal University of Pelotas, city of Capão do Leão, with geographic coordinates of 3152'00"S and 5221'24"O, and altitude of 13.24 meters. The climate is classified by Köppen as Cfa subtropical, and the soil dystrophic yellow red Argisol (Santos et al., 2006).

\section{Genotypes utilized and experimental design}

The crosses that originated the hybrids were carried on the growing season of 2013/2014, with the genitors described on the Table 1 . On the growing season of $2014 / 2015$, the hybrids were arranged in randomized blocks, being 13 treatments with 5 repetitions. The treatments were composed by the hybrids $\left(\mathrm{H}_{1}\right): G 2 \times G 4,\left(\mathrm{H}_{2}\right): G 1 \times G 2,\left(\mathrm{H}_{3}\right)$ : $G 1 \times G 3,\left(H_{4}\right): G 5 \times G 2,\left(H_{5}\right): G 3 \times G 4,\left(H_{6}\right): G 5 \times G 4,\left(H_{7}\right): G 2$ $X G 1,\left(H_{8}\right): G 5 X G 1,\left(H_{9}\right): G 4 X G 1,\left(H_{10}\right): G 4 X G 5,\left(H_{11}\right) G 3 X$ $G 1,\left(H_{12}\right): G 4 \times G 2,\left(H_{13}\right): G 1 \times G 5$.

The experimental units were composed by two lines of five meters length each, spaced 0.7 meters. For each experimental unit, the plants were thinned to adjust the population density of 60.000 plants $\mathrm{ha}^{-1}$. The agronomic 
practices were conducted according to the technical recommendations for maize crop (Embrapa, 2013). Preventive management for pests and weeds was utilized as advised.

\section{Evaluated traits}

The traits of agronomic interest were determined based on the methodology proposed by Carvalho et al. (2014), sampling ten plants randomly in each experimental unit. The measured traits were: Plant height $(\mathrm{PH})$, in centimeters $(\mathrm{cm})$; Spike insertion height $(\mathrm{SH})$, in meters $(\mathrm{m})$; Stem diameter (STD), in millimeters ( $\mathrm{mm})$; Spike diameter (SD), in millimeters $(\mathrm{mm})$; Spike length $(\mathrm{SL})$, in centimeters $(\mathrm{cm})$; Spike mass (SM), in grams (g); number of rows of grains per spike (NRG), in unities; number of grains per row (NGR), in unities; cob diameter $(C D)$, in millimeters $(\mathrm{mm})$; cob mass (CM), in grams (g); spike grains mass (SGM), in grams (g); mass of a thousand grains (MTG), results expressed in grams (g); grain length $(\mathrm{GL})$, in $\mathrm{mm}(\mathrm{mm})$; grain yield $(\mathrm{GY})$, in $\mathrm{kg}$ ha

\section{Statistical analysis}

The data was submitted to variance analysis by the test $\mathrm{F}$ at $5 \%$ probability. The presuppositions were verified through the residues normality obtained by the Shapiro-Wilk (1965) test, and variances homogeneity was evaluated by the Barlett (Steel et al., 1997) test. Posteriorly, additional analyses were preceded though the Tukey test. The linear associations were obtained through Pearson's linear correlation, and the correlation magnitudes followed classification proposed by Carvalho et al. (2004). The phenotypic matrix was submitted to collinearity diagnostic aiming to reveal the matrix number of conditions (NC). The diagnostic of multicollinearity between traits of the phenotypic matrix indicated NC $<100$, representing weak multicollinearity (Montgomery and Peck, 1981). Carvalho and Cruz (1996) suggest the path analysis with collinearity with all traits. Thereby, it was proceeded the path analysis using grain yield as the dependent trait (Cruz et al., 2012). Aiming to verify the genetic variation among the intervarietal hybrids, we analyzed the canonical variates following methodology of Cruz et al. (2012). The statistical analysis was effected though the software (Cruz, 2013).

\section{Conclusion}

The hybrid $\mathrm{H}_{5}$ : $G 3 \times \mathrm{G} 4$ showed increased grain yield, spike grains mass, number of grains per row and spike diameter. Grain yield of intervarietal hybrids presented positive correlations with the traits stem diameter, spike diameter, spike length, number of grains per row, mass of a thousand grains, grain length and spike grains mass. The traits spike diameter and spike length presented higher direct effects on grain yield of intervarietal hybrids. The canonical variates revealed the formation of five groups of intervarietal hybrids phenotypically distinct.

\section{Acknowledgement}

The authors wish to thank the National Council for Scientific and Technological Development (CNPq), and the
Coordination for the Improvement of Higher Education Personnel (CAPES), for the support.

\section{References}

Balbinot Júnior AA, Backes RL, Alves AC, Ogliari JB, Fonseca, JA (2005) Contribution of yield components on grain yield in maize open pollinated varieties. Rev Bras Agrociên. 11(2): 161-166.

Barbosa MH, Carvalho IR, Nardino M, Follmann DN, Olivoto T, Souza VQ (2016) Phenotypic effects and genetic dissimilarity in maize. J Agric Technol Sci. 10(2): 39-44.

Baretta D, Nardino M, Carvalho IR, Pelegrin AJ, Ferrari M, Szareski VJ, Barros WS, Souza VQ, Oliveira AC, Maia LC (2017) Estimates of genetic parameters and genotypic values prediction in maize landrace populations by REML/BLUP procedure. Genet Moler Res. 16: 1-14.

Carvalho IR, De Souza VQ, Follmann DN, Nardino M, Schmidt, D (2014) Desempenho agronômico de híbridos de milho em ambiente irrigado e sequeiro. Enciclop Bios. 10(18): 1144-1153.

Carvalho IR, Pelegrin AJ, Szareski VJ, Ferrari M, Rosa TC, Martins TS, Santos NL, Nardino M, Souza VQ, Oliveira AC, Maia LC (2017) Diallel and prediction (REML/BLUP) for yield components in intervarietal maize hybrids. Genet Mole Res. 16: 1-12.

Carvalho IR, Pelegrin AJ, Ferrari M, Szareski VJ, Rosa TC, Oliveira VF, Hoffmann JF, Nardino M, Chaves FC, Souza VQ, Oliveira AC, Maia LC (2018) Heterosis and genetics parameters for yield and nutritional components in halfsibling maize progenies. Genet Mole Res. 17: 1-12.

Carvalho IR, Szareski VJ, Mambrin RB, Ferrari M, Pelegrin AJ, Rosa TC, Peter M, Silveira DC, Conte GG, Barbosa MH, Souza VQ. (2018) Biometric models and maize genetic breeding a review. Aust J Crop Sci, 12:1796-1805.

Carvalho FIF, Lorencetti C, Benin, G (2004) Estimativas e implicações da correlação no melhoramento vegetal. Pelotas: UFPel. 142p.

Carvalho SP, Cruz CD (1996) Diagnosis of multicollinearity: assessment of the condition of correlation matrices used in genetic studies. Braz J Genet. 19: 479-484.

Churata BGM, Ayala-Osuna, JT (1996) Correlações genotípica, fenotípica e de ambiente e análise de trilha em caracteres avaliados no composto de milho (Zea mays) arquitetura. Rev Cer. 43(249): 628-636.

Conab - National Supply Company (2016) - Brazilian Crop Assessment. Fifth assessment February 2016, vol. 3, n. 5. Available in: <http://www.conab.gov.br>.

Cruz CD, Regazzi AJ, Carneiro, PCS (2004) Modelos biométricos aplicado ao melhoramento genético. 3.ed. Viçosa, MG: Publishing Company of the UFV. 192p.

Cruz CD, Carneiro, PCS (2003) Modelos biométricos aplicado ao melhoramento genético. 2.ed. Viçosa, MG: Publishing Company of the UFV.356p.

Cruz CD, Regazzi, AJ (1997) Modelos biométricos aplicados ao melhoramento genético. 2.ed. Viçosa: UFV. 390p.

Cruz CD, Regazzi AJ, Carneiro, PCS (2012) Modelos biométricos aplicados ao melhoramento genético. Volume 2, 3a ed. Viçosa: Publishing Company of the UFV. 514p.

Cruz CD (2013) Genes: um pacote de software para análise em estatística experimental e genética quantitativa. Acta Scient Agron. 35(3): 271-276. 
Cruz SCS, Pereira FRS, Santos JR, Albuquerque AW, Pereira RG (2008) Nitrogen fertilization for corn cultivated under a no-tillage system in the State of Alagoas, Brazil. Rev Bras De Eng Agríc Amb. 12(1): 62-68.

Da Rosa TC, Carvalho IR, Szareski VJ, Pelegrin AJ, Barbosa MH, Santos NL, Martins TS, Uliana AS, Souza VQ (2018) Agronomic Performance and Multivariate Analysis Applied to Three-Waycross Maize Hybrids. J Agric Sci. 10: 319-328.

Demari GH, Carvalho IR, Nardino M, Szareski VJ, Dellagostin SM, Rosa TC, Follmann DN, Monteiro MA, Basso CJ, Pedo T, Aumonde TZ, Zimmer PD (2016) Importance of nitrogen in maize production. Int J Curr Res. 8: 36629-36634.

Demari GH, Carvalho IR, Szareski VJ, Follmann DN, Souza VQ, Basso CJ (2018) Nitrogen sources and splitting in genetically modified maize hybrids. Revista de Ciências Agroveterinárias. 17, 325-335.

oná S, Paterniani MEAGZ, Gallo PB, Duarte AP (2011) Heterosis and its components in F2 populations of maize hybrids. Bragantia. 70(4): 767-774.

Brazilian Agricultural Research Corporation (2013) Indicações técnicas para o cultivo de milho e de sorgo no Rio Grande do Sul safras 2013/2014 e 2014/2015.

Entringer GC, Santos PHAD, Vettorazzi JCF, Cunha KS, Pereira MG (2014) Correlation and path analysis for yield components of supers weet corn. Rev Ceres. 61(3): 356361.

Fancelli AL, Dourado-Neto D (1999) Tecnologia da produção de milho. Piracicaba: FEALQ/ ESALQ/USP. 360p.

Fancelli AL, Dourado Netto D (2000) Produção de milho. Guaíba: Agropecuária. 360p.

Fernandes FCS, Arf SBO, Andrade JAC (2010) Nitrogen doses, use and efficiency in six corn cultivars. Rev Bras de Milho e Sorgo. 4(02): 195-204.

Gilo EG, Silva Junior CA, Torres FE, Nascimento ES, Lourenção AS (2011) Behavior of corn hybrids in cerrado sul-mato-grossense under diferente row spacing. Biosc J. 27(6): 908-914.

Goes R J, Rodrigues RAF, Arf O, Vilela RG (2012) Side dress nitrogen application in maize (Zea mays I.) in no-tillage system at second season. Rev Bras de Milho and Sorgo. 11: 169-177.

Hallauer AR, Carena MJ, Miranda Filho JB (2010) Quantitative genetics in maize breeding. Ames: lowa State University Press, 663p.

Jasdanwala RT, Khan AA (1988) Assimilate distribution in flowering maize plants. J Agron Crop Sci. 161(4): 249-255.

Lima MLA, Junior CLS, Bento DAV, de Souza AP, CarliniGarcia LA (2006) Mapping QTL for grain yield and plant traits in a tropical maize population. Mol Breed. 17(3): 227-239.

Lopes SJ, Lúcio AD, Storck L, Damo HP, Brum B, Santos VJ (2007) Path analysis on maize spikes characteristics related of the hybrid type. Ciên Rur. 37(6): 1536-1542.

Kleinpaul J, Burin C, Alves B, Toebe M, Facco G, Santos G (2014) Genotypic correlation and trail analysis in earlycycle maize cultivars. Rev da Estat.da Univ Fed.de Ouro Pr. 3(3): 304-308.

Magalhães PC, Durães FOM (2006) Fisiologia da Produção de Milho. Embrapa Milho e Sorgo, Minas Gerais, Circular Técnica. 76: 1-10.
Miranda GV, Coimbra RR, Godoy CL, Souza LV, Guimarães LM, Melo AV (2003) Potential to breeding and genetic divergence in pop corn cultivars. Braz J Agricul Res. 38(6): 681-688.

Miranda Filho J B, Viégas GP (1987) Milho híbrido. In: Parteniani E, Viègas GP Melhoramento e produção de milho. Campinas: Fundação Cargill. 1: 275-340p.

Montgomery DC, Peck EA (1981) Introduction to linear regression analysis. J. Willey, New York, 504p.

Moore David S (2007) The Basic Practice of Statistics. New York, Freeman.

Nardino M, Baretta D, Carvalho IR, Olivoto T, Follmann DN, Pelegrin AJ, Szareski VJ, Lautenchleger F, Rosa TC, Barbosa MH, Konflanz VA, Barros WS, Souza VQ (2018) Environment Stratification in the Evaluation of Corn Hybrids in Southern Brazil. J Agricl Sci. 10: 333-341.

Nardino M, Baretta D, Carvalho IR, Olivoto T, Pelegrin AJ, Ferrari M, Szareski VJ, Konflanz VA, Caron BO, Schmidt D, Barros WS, Souza VQ (2016) REML / BLUP in analysis of pre-commercial simple maize hybrid. Int J Current Res. 8: 37008-37013.

Nardino M, Baretta D, Carvalho IR, Follmann DN, Ferrari M, Pelegrin AJ, Szareski VJ, Konflanz VA, Souza VQ (2017) Genetic divergence among corn (Zea mays L.) genotypes in distinct environments. Revista de Ciências Agrárias (Lisboa). 40: 164-174.

Nardino M, Baretta D, Carvalho IR, Olivoto T, Follamann DN, Szareski VJ, Ferrari M, Pelegrin AJ, Konflanz VA, Souza VQ (2016) Restricted maximum likelihood/best linear unbiased prediction (REML/BLUP) for analyzing the agronomic performance of corn. Afr J Agric Res. 11: 48644872.

Pelegrin AJ, Carvalho IR, Nunes ACP, Demari GH, Szareski VJ, Barbosa MH, Rosa TC, Ferrari M, Nardino M, Santos OP, Resende MDV, Souza VQ, Oliveira AC, Maia LC (2017) Adaptability, stability and multivariate selection by mixed models. Am J Plant Sci. 17: 3324-3337.

Pimentel Gomes F (2009). Curso de estatística experimental. 15.ed. Piracicaba: FEALQ. 451p.

Possamai JM, Souza CM, Galvão JCC (2001) Soil preparation systems for the safrinha corn. Bragantia. 60(2): 79-82.

Ramalho MAP, Santos JB, Pinto CABP (2012) Genética na agropecuária. 5a ed. Lavras: Editora UFLA. 566p.

Santos HG, Jacomine PKT, Anjos LHC, Oliveira VA, Oliveira JB, Coelho MR, Lumbreras JF, Cunha TJF (2006) Brazilian system of soil classification. Rio de Janeiro: Embrapa Solos. $306 \mathrm{p}$.

Scapim CA, Carvalho CGP, Cruz CD (1995) A proposal of variation coefficient classification for corn growing. Braz $\mathrm{J}$ Agric Res. 30: 683-686.

Silva E C, Buzetti S, Guimarães GL, Lazarini E, Sá ME (2005) Rates and timing of nitrogen application in corn under notillage on a red latosol. Rev. Bras. de Ciênc. Do Solo. 29: 353-362.

Silva JGC (2003) Estatística básica. Federal University of Pelotas.

Shapiro SS, Wilk MB (1965) An Analysis of Variance Test for Normality (Complete Samples). Biometrika. 52(3/4).

Steel RGD, Torrie JH, Dickey DA (1997) Principles and procedures of statistics: a biometrical approach. 3aed. New York: McGraw Hill Book, 666p. 
Szareski VJ, Carvalho IR, Kehl K, Pelegrin AJ, Nardino M, Demari GH, Barbosa MH, Lautenchleger F, Smaniotto F, Aumonde TZ, Pedo T, Souza VQ (2018) Interrelations of Characters and Multivariate Analysis in Corn. J Agric Sci. (10): 187-194.

Szareski VJ, Carvalho IR, Kehl K, Levien AM, Rosa TC, Barbosa MH, Demari GH, Pimentel JR, Troyjack C, Martinazzo EG, Souza VQ, Villela FA, Pedo T, Aumonde TZ (2018) Research Article Phenotypic and predicted genetic approaches for genotype ranking of wheat seed yield in Brazil. Genet Mole Res. 17: 1-13.
Troyjack C, Pimentel JR, Dubal ITP, Escalera RAV, Jaques LA, Koch F, Monteiro MA, Demari GH, Szareski VJ, Carvalho IR, Schuch LOB, Aumonde TZ, Pedo T (2018) Nitrogen fertilization on maize sowing: plant growth and seed vigor. Am J Plant Sci. 9: 83-97.

Vencovsky R, Barriga P (1992) Genética biométrica no fitomelhoramento. Rev Bras De Gen. 496p.

Vilela RG, Arf O, Kappes C, Kaneko FH, Gitti DC, Ferreira JP (2012) Agronomic performance of corn hybrids as a function of foliar application of fungicides. Biosc J. 28(1): 25-33.

Wright S (1921) Correlation and causation. J Agric Res. 20: 557-585. 